\title{
MODIFICATION OF GLYCOPEPTIDE ANTIBIOTIC EREMOMYCIN BY THE ACTION OF ALKYL HALIDES AND STUDY ON ANTIBACTERIAL ACTIVITY OF THE COMPOUNDS OBTAINED
}

\author{
A. Y. Pavlov, E. N. Olsufyeva, T. F. Berdnikova, \\ I. V. Malkova and M. N. Preobrazhenskaya \\ Institute of New Antibiotics of the Russian Academy of Medical Sciences, \\ Moscow 119867, B. Pirogovskaya 11, Russia \\ G. D. RISBRIDGER \\ SmithKline Beecham Pharmaceuticals, \\ Brockham Park, Betchworth, Surrey RH3 7AJ, United Kingdom \\ (Received for publication October 13, 1993)
}

\begin{abstract}
Alkylation of glycopeptide antibiotic eremomycin by the action of different alkyl halides leads, depending on the structure of alkyl halides used, to eremomycin derivatives of six types; alkylated at the $N$-terminus, quaternary compounds at the $N$-terminus, eremomycin esters, esters of eremocycin alkylated at the $N$-terminus, esters of eremomycin quaternised at the $N$-terminus, esters of eremomycin alkylated both at the $N$-terminus and at the aminogroup of disaccharide branch. Five compounds demonstrated high antibacterial activity in vitro, $N$-allyleremomycin and methyl ester of $N, N$-dimethyleremomycin being at least as good as the parent eremomycin.
\end{abstract}

Eremomycin ${ }^{1)}$ is a glycopeptide antibiotic of dalbaheptide group ${ }^{2)}$ identical to antibiotic $\mathrm{A} 82846 \mathrm{~A}^{3)}$ and antibiotic MM452894). It is suitable for treatment of severe Gram-positive infections and is now under preparation for clinical trial in Russia. The mechanism of action of eremomycin is similar to that of other glycopeptide antibiotics: it binds to the terminal D-alanyl-D-alanine of the muramylpentapeptide during the biosynthesis of bacterial cell wall peptidogiycan ${ }^{5}$.

The nitrogen atom at the $\mathrm{N}$-terminus of the peptide in eremomycin (Ere) is designated as $\mathrm{N}$, the nitrogen atom in disaccharide branch as $\mathrm{N}^{\prime}$, and the nitrogen atom in monosacchride branch is designated as $\mathrm{N}^{\prime \prime}$. Recently a series of different $N$-alkylderivatives was obtained by the reductive alkylation of Ere ${ }^{6,7)}$. During the process of reductive alkylation, aldehydes in the presence of $\mathrm{NaBH}_{3} \mathrm{CN}$ first interact with the $\mathrm{N}^{\prime} \mathrm{H}_{2}$ group in disaccharide branch of Ere, then with the $\mathrm{NHCH}_{3}$ group; the reactivity of the $\mathrm{N}^{\prime \prime} \mathrm{H}_{2}$ group in this reaction is the lowest. Acylation of Ere led first to $N$-acylderivatives, $N^{\prime}$-acylated compounds being isolated as minor reaction products ${ }^{6,7)}$. Different esters of Ere were obtained by the interaction of the antibiotic with diazoalkanes ${ }^{8}$.

In our studies on eremomycin, our attention was focused on the relationship between the level and type of alkylation of amino moieties, especially at the $\mathrm{N}$-terminus of the antibiotic and the antibacterial activity. The influence of the transformation of $\mathrm{COOH}$ group at the $C$-terminus into an ester on the antibacterial activity of these alkylated eremomycins was also investigated. Herein, we wish to report the chemical transformation of eremomycin by the action of alkyl and arylalkyl halides.

\section{Chemistry}

A series of alkyl derivatives of eremomycin was prepared by the interaction of Ere with alkyl or 


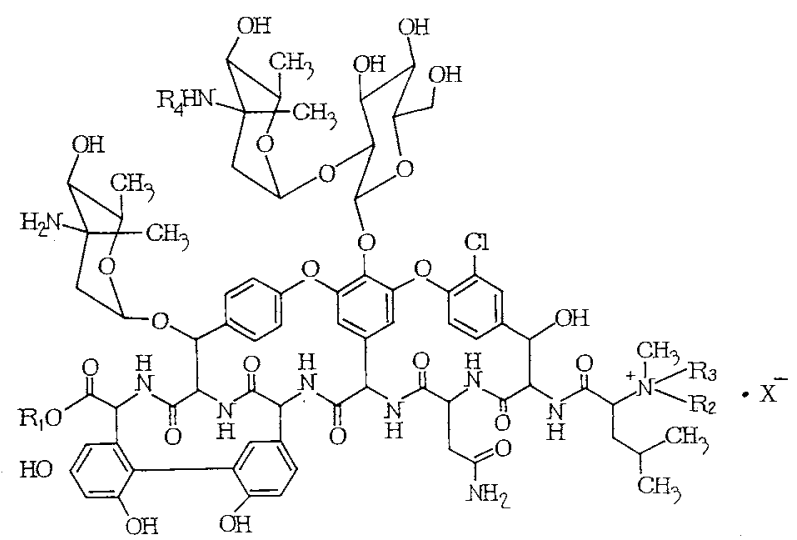

$\begin{array}{lll}\text { Type I: } & \text { Ib } & \mathrm{R}_{1}=\mathrm{R}_{2}=\mathrm{R}_{4}=\mathrm{H} ; \mathrm{R}_{3}=\mathrm{CH}_{2} \mathrm{CH}=\mathrm{CH}_{2} \\ \text { Type II: } & \text { IIa } & \mathrm{R}_{1}=\mathrm{R}_{4}=\mathrm{H} ; \mathrm{R}_{2}=\mathrm{R}_{3}=\mathrm{CH}_{3} \\ & \text { IIb } & \mathrm{R}_{1}=\mathrm{R}_{4}=\mathrm{H} ; \mathrm{R}_{2}=\mathrm{R}_{3}=\mathrm{CH}_{2} \mathrm{CH}=\mathrm{CH}_{2} \\ \text { Type III: } & \text { IIId } & \mathrm{R}_{1}=n-\mathrm{C}_{3} \mathrm{H}_{7} ; \mathrm{R}_{2}=\mathrm{R}_{3}=\mathrm{R}_{4}=\mathrm{H} \\ & \text { IIIe } & \mathrm{R}_{1}=n-\mathrm{C}_{7} \mathrm{H}_{15} ; \mathrm{R}_{2}=\mathrm{R}_{3}=\mathrm{R}_{4}=\mathrm{H} \\ & \text { IIIf } & \mathrm{R}_{1}=n-\mathrm{C}_{12} \mathrm{H}_{15} ; \mathrm{R}_{2}=\mathrm{R}_{3}=\mathrm{R}_{4}=\mathrm{H} \\ & \text { IIIg } & \mathrm{R}_{1}=n-\mathrm{C}_{18} \mathrm{H}_{37} ; \mathrm{R}_{2}=\mathrm{R}_{3}=\mathrm{R}_{4}=\mathrm{H} \\ \text { Type IV: } & \text { IVc } & \mathrm{R}_{1}=\mathrm{R}_{2}=\mathrm{CH}_{2} \mathrm{C}_{6} \mathrm{H}_{5} ; \mathrm{R}_{3}=\mathrm{R}_{4}=\mathrm{H} \\ & \text { IVd } & \mathrm{R}_{1}=\mathrm{R}_{2}=n-\mathrm{C}_{3} \mathrm{H}_{7} ; \mathrm{R}_{3}=\mathrm{R}_{4}=\mathrm{H} \\ & \text { IVe } & \mathrm{R}_{1}=\mathrm{R}_{2}=n-\mathrm{C}_{7} \mathrm{H}_{15} ; \mathrm{R}_{3}=\mathrm{R}_{4}=\mathrm{H} \\ \text { Type V: } & \text { Va } & \mathrm{R}_{1}=\mathrm{R}_{2}=\mathrm{R}_{3}=\mathrm{CH}_{3} ; \mathrm{R}_{4}=\mathrm{H} \\ \text { Type VI: } & \text { VIc } & \mathrm{R}_{1}=\mathrm{R}_{2}=\mathrm{R}_{4}=\mathrm{CH}_{2} \mathrm{C}_{6} \mathrm{H}_{5} ; \mathrm{R}_{3}=\mathrm{H} \\ & \text { VId } & \mathrm{R}_{1}=\mathrm{R}_{2}=\mathrm{R}_{4}=n-\mathrm{C}_{3} \mathrm{H}_{7} ; \mathrm{R}_{3}=\mathrm{H} \\ & \text { VIe } & \mathrm{R}_{1}=\mathrm{R}_{2}=\mathrm{R}_{4}=n-\mathrm{C}_{7} \mathrm{H}_{15} ; \mathrm{R}_{3}=\mathrm{H}\end{array}$

arylalkyl halides in DMSO in the presence of $\mathrm{NaHCO}_{3}$. Depending on the nature of alkylating agents, six types of Ere derivatives were obtained:

type I- $N$-alkyl derivative Ib,

type II-quaternary $N$-derivatives (IIa, IIb),

type III-esters of eremomycin (IIId, IIIe, IIIf, IIIg),

type IV-esters of $\mathrm{N}$-alkly derivatives (IVc, IVd, IVe),

type $\mathrm{V}$-methyl ester of quaternary derivative $\mathbf{V a}$,

type VI-esters of $N, N^{\prime}$-dialkyl derivatives (VIc, VId, VIe).

The most reactive alkyl halides $\left(\mathrm{CH}_{3} \mathrm{I}\right.$ or $\left.\mathrm{CH}_{2}=\mathrm{CHCH}_{2} \mathrm{I}\right)$ attack first the $\mathrm{NHCH}_{3}$ group of the peptide to give the compounds of types I and II, and then the carboxy group is alkylated. This sequence of events is evident if reaction is monitored by TLC. Thus, by the interaction of Ere with methyl iodide, quaternary salt IIa and its methyl ester Va were isolated with yields of $45 \%$ and $20 \%$, respectively. In similar conditions, interaction of Ere with allyl iodide gave a mixture of products with $N$-allyleremomycin (Ib) as a major product (shown by TLC). Increasing the quantities of allyl iodide and $\mathrm{NaHCO}_{3}$, as well as the reaction time, led to the formation of two products: Ib (35\%) and its quaternary salt IIb (25\%).

In contrast to methyl iodide and allyl iodide, interaction of benzyl chloride with Ere did not produce quaternized derivatives. In this case, benzyl esters of $N$-benzyleremomycin (IVc) and of $N, N^{\prime}$-dibenzyleremomycin (VIc) were isolated in yields of $20 \%$ and $12 \%$, respectively. It suggests that the absence of quaternized compounds among reaction products in this case is the result of steric hindrance displayed 
Table 1. Results of analytical investigation of compounds $\mathbf{I} \sim \mathbf{V I}$.

\begin{tabular}{|c|c|c|c|c|c|c|}
\hline \multirow{2}{*}{ Compound } & \multicolumn{2}{|c|}{$\begin{array}{c}\text { Acidic hydrolysis presence of } \\
\text { eremosamine }\end{array}$} & \multirow{2}{*}{$\begin{array}{c}\text { Edman degrada- } \\
\text { tion (presence } \\
\text { of } N \text {-methyl- } \\
\text { leucine at the } \\
\quad N \text {-end) }\end{array}$} & \multirow{2}{*}{$\begin{array}{l}{ }^{1} \mathrm{H} \text { NMR data } \\
\text { (number of } \\
\text { introduced } \\
\text { alkyl groups) }\end{array}$} & \multirow{2}{*}{$\begin{array}{l}\text { IR spectro- } \\
\text { scopy data } \\
\text { (presence of } v_{\mathrm{co}} \\
\text { at } 1750 \mathrm{~cm}^{-1} \text { ) } \\
(\mathrm{COOR})\end{array}$} & \multirow{2}{*}{$\begin{array}{l}{[\alpha]_{\mathrm{D}}^{22}(\mathrm{C} 1)} \\
\text { (Solvent) }\end{array}$} \\
\hline & $\begin{array}{l}\text { in disaccharide } \\
\text { branch }\end{array}$ & $\begin{array}{l}\text { in monosac- } \\
\text { charide branch }\end{array}$ & & & & \\
\hline Ere & + & + & + & - & - & $-100^{\circ}\left(\mathrm{H}_{2} \mathrm{O}\right)$ \\
\hline Ib & + & + & - & 1 & - & $-101^{\circ}\left(\mathrm{H}_{2} \mathrm{O}\right)$ \\
\hline IIa & + & + & - & 2 & - & $-104^{\circ}\left(\mathrm{H}_{2} \mathrm{O}\right)$ \\
\hline IIb & + & + & - & 2 & - & $-103^{\circ}\left(\mathrm{H}_{2} \mathrm{O}\right)$ \\
\hline IIId & + & + & + & 1 & + & $-94^{\circ}\left(\mathrm{H}_{2} \mathrm{O}\right)$ \\
\hline IIIe & + & + & + & 1 & + & $-96^{\circ}(\mathrm{MeOH})$ \\
\hline IIIf & + & + & + & 1 & + & $-97^{\circ}(\mathrm{MeOH})$ \\
\hline IIIg & + & + & + & 1 & + & $-92^{\circ}(\mathrm{MeOH})$ \\
\hline IVe & + & + & - & 2 & + & $-100^{\circ}(\mathrm{MeOH})$ \\
\hline IVd & + & + & - & 2 & + & $-96^{\circ}\left(\mathrm{H}_{2} \mathrm{O}\right)$ \\
\hline IVe & + & + & - & 2 & + & $-94^{\circ}(\mathrm{MeOH})$ \\
\hline Va & + & + & - & 3 & + & $-103^{\circ}\left(\mathrm{H}_{2} \mathrm{O}\right)$ \\
\hline VIc & - & + & - & 3 & + & $-100^{\circ}(\mathrm{MeOH})$ \\
\hline VId & - & + & - & 3 & + & $-99^{\circ}\left(\mathrm{H}_{2} \mathrm{O}\right)$ \\
\hline VIe & - & + & - & 3 & + & $-101^{\circ}\left(\mathrm{H}_{2} \mathrm{O}\right)$ \\
\hline
\end{tabular}

by the bulky benzyl group.

As in the acylation of eremomycin, the reaction of alkyl halides with the $\mathrm{NHCH}_{3}$ group was more reactive than the $\mathrm{N}^{\prime} \mathrm{H}_{2}$ amino group of disaccharide moiety.

Less reactive propyl iodide and heptyl iodide first attack the carboxy group to yield corresponding esters, then the $\mathrm{NHCH}_{3}$ group at the $\mathrm{N}$-terminus and finally the $\mathrm{N}^{\prime} \mathrm{H}_{2}$ group. By the interaction of Ere with PrI, the propyl ester of eremomycin (IIId), the propyl ester of $N$-propyleremomycin (IVd) and the propyl ester of $N, N^{\prime}$-dipropyleremomycin (VId) were isolated with the yields $17 \%, 13 \%$ and $6 \%$, respectively.

Similarly, heptyl iodide yields heptyl esters of Ere (IIIe), of $N$-heptyleremomycin (IVe), and of $N, N^{\prime}$-diheptyleremomycin (VIe) with the yields $18 \%, 16 \%$ and $12 \%$, respectively.

Interaction of Ere with dodecyl or octadecyl bromides also produced mixtures of products of types III, IV and VI as it was demonstrated by TLC. We used the reaction conditions ( $40 \sim 45^{\circ} \mathrm{C}$ and $4 \sim 8$ hours) which permitted the production of only esters (type III compounds), which were separated from the starting Ere by extraction with butanol. Using this approach, heptyl, dodecyl and octadecyl esters of eremomycin (IIIe, IIIf and IIIg) were isolated in the yields $15 \%, 15 \%$ and $13 \%$, respectively.

Purification of the compounds obtained was performed with the use of ion-exchange chromatography on CM-cellulose by the method which was successfully used for the purification of the methyl ester of eremomycin ${ }^{8)}$. The lipophilic compounds IVc, VIc, IVe, VIe, which were insoluble in water, were purified by preparative TLC.

Analytical investigation of the compounds obtained is summarized in the Table 1. Positions of the introduced alkyl groups were determined after acidic hydrolysis and Edman degradation. Previously it was demonstrated that hydrolysis in $0.2 \mathrm{~N} \mathrm{HCl}$ at $100^{\circ} \mathrm{C}$ of eremomycin during 10 minutes leads to the splitting of the glycosidic bond between two sugars in the disaccharide branch and gives rise to eremosamine ${ }^{6}$. Comparison by TLC of hydrolysis products of compounds I $\sim$ VI with the authentic sample of eremosamine demonstrated that among products of hydrolysis of $\mathbf{I} \sim \mathbf{V}$, eremosamine is present; while 
aminosugars formed after hydrolysis of compounds VI are different from eremosamine. Hydrolysis in more drastic conditions $\left(1 \mathrm{~N} \mathrm{HCl}, 100^{\circ} \mathrm{C}, 30\right.$ minutes), when glucose as well as eremosamine from monosaccharide branch are released, gave for all the compounds obtained (I VI) eremosamine.

Edman degradation" ${ }^{9)}$ confirmed that in all the compounds I, II, IV, V, VI, the $N$-methylaminogroup is substituted: TLC demonstrated the absence of 5-isopropyl-1-methyl-3-phenyl-2-thiohydantoin by the comparison with an authentic sample of the latter, which was obtained in a parallel experiment by Edman degradation of eremomycin. In eremomycin esters (type III) $\mathrm{NHCH}_{3}$ group is not affected.

Presence of ester groups in the compounds III, IV, and VI is well demonstrated by IR spectroscopy.

In ${ }^{1} \mathrm{H}$ NMR spectra of the compounds obtained, all signals of protons of the eremomycin backbone and of the introduced groups are represented. Comparison of ${ }^{1} \mathrm{H}$ NMR spectra of IIa with Ere demonstrates the presence of a nine proton singlet at $3.2 \mathrm{ppm}$ which corresponds to three $N$-methyl groups; in the ${ }^{1} \mathrm{H}$ NMR spectrum of $\mathbf{V a}$, additionally to this nine proton singlet of three $N$-methyl groups at $3.20 \mathrm{ppm}$ a singlet of COOMe group at $3.80 \mathrm{ppm}$ is present. In ${ }^{1} \mathrm{H}$ NMR spectra of allyl derivatives Ib and IIb, multiplets at $6.0 \sim 5.5 \mathrm{ppm}$ are present, and benzyl derivatives demonstrate multiplets in low field at $7.6 \sim 7.3 \mathrm{ppm}$. In ${ }^{1} \mathrm{H}$ NMR spectra of propyl, heptyl, dodecyl and octadecyl compounds, signals of terminal aliphatic $\mathrm{CH}_{3}$ group of the introduced fatty acid substituents at $0.8 \mathrm{ppm}$ and signals of $\mathrm{CH}_{2}$ groups (except those attached to a heteroatom) can be identified at $1.0 \sim 1.2 \mathrm{ppm}$.

For the most biologically active compounds (Ib, IIa, IIb, IIId and Va), HPLC demonstrated that the amount of the parent Ere is lower than $1 \%$.

\section{Analysis of New Glycopeptides by Fast Atom Bombardment (FAB) and Ionspray Mass Spectroscopy}

FAB and ionspray (pneumatically assisted electrospray) mass spectroscopy has provided molecular weight information of five glycopeptide samples (Ib, IIa, IIb, IIId and Va). The signals observed by FAB were very weak and several scans were accumulated to obtain reasonable spectra. The FAB analysis was slow, each sample required 30 to 40 minutes analysis time. The ionspray spectra were most intense and showed doubly charged ions as major ions in each spectrum. Weak $(\mathbf{M}+\mathrm{H})^{+}$ions were detected and significant fragment ions corresponding to successive losses of sugar groups were also observed. The ionspray data was obtained by a rapid flow injection technique and each sample was analyzed within 5 minutes. The FAB mass spectra of compounds IIa, IIb, IIId, Va all confirm the expected molecular weights $(1,584,1,636,1,598,1,598$, respectively). The spectrum of $\mathbf{I b}$ indicates a $\mathrm{MW}$ of 1,598, 2amu higher than expected for $\mathrm{N}$-allyleremomycin. For mass spectrometric investigation we took a sample which previously was used for NMR study in $\mathrm{D}_{2} \mathrm{O}$ solution; as ${ }^{1} \mathrm{H}-{ }^{2} \mathrm{H}$ exchange is rather slow in eremomycin derivatives (more than 10 hours) mass-spectrum of Ia corresponds to dideutero derivative of Ia. The FAB spectrum of IIb shows a weak $(\mathrm{M}+\mathrm{H})^{+}$cluster confirming the expected $\mathrm{MW}$ of 1636 , but the most abundant peak cluster is due to addition of thioglycerol from the FAB matrix.

The positive ion ionspray spectra were obtained for compounds Ib, IIa, IIb, IIId and Va. $(\mathrm{M}+\mathrm{H})^{+}$ peaks are very small in all five spectra. However, the presence of intense doubly charged peaks $(\mathrm{M}+2 \mathrm{H})^{2+}$ (794.2, 819.8, 800.8 and 800.8 for IIa, IIb, IIId and Va, respectively) provides the required molecular weight information. Again Ib shows a doubly charged species at 800.3 indicating a MW of 1598 which corresponds to a dideuterated compound.

The ionspray spectra show fragment ions indicating common losses from all 5 glycopeptides. The 
spectra show 2 successive losses of $142 \mu$ followed by a further loss of $162 \mu$. The FAB spectra generally show a loss of $142 \mu$ followed by a loss of $162 \mu$ but the signals were very weak (signal: noise typically $3: 1)$. These fragmentations are due to losses of the sugars eremosamine (142) and glucose (162).

The results of these experiments clearly show that ionspray ionisation is the most efficient technique for the analysis of glycopeptides. Ionspray provides more intense spectra than FAB and the analysis is both more straightforward and faster.

\section{Antibacterial Activity}

Table 2 shows the in vitro antibacterial activity against Bacillus subtilis and 25 methicillin-resistant strains of clinical isolates of Staphylococcus aureus of all synthesized compounds in comparison with the parent Ere and vancomycin. The activity of compounds Ib, IIa, IIb, IIId, Va against B. subtilis is comparable with the activity of vancomycin and of eremomycin or is $2 \sim 4$ times lower. Other compounds have lower antibacterial activity. Against $S$. aureus, Ib, IIa, IIb, IIId and Va are $4 \sim 8$ times less active than eremomycin and comparable with vancomycin. Compounds IIIe, IIIf and IVd are moderately active; IIIg, IVc, IVe, VIc, VId, VIe have lower of activity.
Table 2. In vitro activity against $B$. subtilis and $25 \mathrm{MR}$ strains of $S$. aureus of derivatives $\mathbf{I} \sim$ VI in comparison with eremomycin and vancomycin.

\begin{tabular}{ccc}
\hline Compound & $\begin{array}{c}\text { B. subtilis } \\
\mathrm{MIC}(\mu \mathrm{g} / \mathrm{ml})\end{array}$ & $\begin{array}{c}\text { S. aureus } \\
\mathrm{MIC}_{50}(\mu \mathrm{g} / \mathrm{ml})\end{array}$ \\
\hline Ere & 0.16 & 0.5 \\
Vancomycin & 0.16 & 2 \\
Ib & 0.16 & 4 \\
IIa & 0.32 & 2 \\
IIb & 0.64 & 4 \\
IIId & 0.64 & 2 \\
IIIe & 1.28 & 8 \\
IIIf & 1.28 & 8 \\
IIIg & 3.20 & 64 \\
IVc & 1.92 & 32 \\
IVd & 1.28 & 8 \\
IVe & 1.60 & 16 \\
Va & 0.64 & 2 \\
VIc & 2.24 & 32 \\
VId & 1.60 & 16 \\
VIe & 1.92 & 32 \\
\hline
\end{tabular}

Table 3. Antibacterial evaluation of compounds Ib, IIa, IIb, IIId and Va against series of Gram-positive bacteria in comparison with eremomycin and vancomycin.

\begin{tabular}{|c|c|c|c|c|c|c|c|}
\hline \multirow{2}{*}{ Organism } & \multicolumn{7}{|c|}{$\mathrm{MIC}(\mu \mathrm{g} / \mathrm{ml})$} \\
\hline & $\begin{array}{l}\text { Eremo- } \\
\text { mycin }\end{array}$ & $\begin{array}{l}\text { Vanco- } \\
\text { mycin }\end{array}$ & Ib & İ́a & IIb & IIId & $\mathbf{V a}$ \\
\hline Bacillus subtilis ATCC 6633 & 0.125 & 1 & 0.25 & 0.25 & 0.125 & 0.25 & 0.125 \\
\hline $\begin{array}{l}\text { Corynebacterium xerosis } \\
\text { NCTC } 9755\end{array}$ & 0.25 & 1 & $\leqslant 0.06$ & 0.125 & 0.125 & 0.125 & $\leqslant 0.06$ \\
\hline Staphylococcus aureus Oxford & 0.5 & 2 & 0.5 & 0.5 & 4 & 2 & 0.25 \\
\hline S. aureus Smith & 0.25 & 2 & 0.5 & 1 & 4 & 1 & 0.5 \\
\hline S. aureus Russel & 0.25 & 2 & 0.5 & 1 & 4 & 2 & 0.5 \\
\hline S. aureus V573 & 0.25 & 2 & 0.5 & 0.25 & 0.5 & 0.5 & 0.25 \\
\hline S. aureus V1100 & 2 & 2 & 0.5 & 4 & 16 & 2 & 0.5 \\
\hline S. aureus Wilson & 0.5 & 2 & 0.5 & 2 & 1 & 2 & 1 \\
\hline S. epidermidis 54815 & 0.25 & 2 & - & 0.5 & 4 & 1 & 0.25 \\
\hline S. epidermidis NCTC11047 & 0.125 & 2 & 0.125 & 0.5 & 1 & 0.5 & 0.25 \\
\hline$S$, saprophyticus FL1 & 0.5 & 2 & $\leqslant 0.06$ & 1 & 4 & 0.25 & 0.125 \\
\hline S. saprophyticus FL2 & 1 & 2 & 1 & 4 & 4 & 4 & 0.5 \\
\hline Micrococcus luteus NCTC 8340 & 0.125 & 2 & 0.125 & 0.25 & 0.5 & $\leqslant 0.06$ & 0.125 \\
\hline Streptococcus agalactiae 2798 & 0.125 & 1 & $\leqslant 0.06$ & $\leqslant 0.06$ & 0.125 & $\leqslant 0.06$ & $\leqslant 0.06$ \\
\hline S. agalactiae Hester & $\leqslant 0.06$ & 1 & $\leqslant 0.06$ & $\leqslant 0.06$ & 0.125 & $\leqslant 0.06$ & $\leqslant 0.06$ \\
\hline S. sanguis ATCC 10556 & 0.5 & 2 & 0.25 & 1 & 2 & 0.5 & 0.25 \\
\hline S. viridans Harding & $\leqslant 0.06$ & 1 & $\leqslant 0.06$ & $\leqslant 0.06$ & 0.125 & $\leqslant 0.06$ & $\leqslant 0.06$ \\
\hline S. faecalis $\mathrm{I}$ & 0.5 & 2 & 0.5 & 1 & 2 & 0.25 & 0.5 \\
\hline S. faecalis $\mathrm{T} 814$ & 1 & 8 & 0.5 & 1 & 1 & 0.5 & 0.5 \\
\hline
\end{tabular}


The most active compounds Ib, IIa, IIb, IIId and Va were investigated against a broad spectrum Gram-positive bacteria including clinical isolates (Table 3) in comparison with eremomycin and vancomycin. In this experiments, all glycopeptides were antibacterially active against Gram-positive bacteria. Antibacterial activity of $\mathbf{V a}$ and $\mathbf{I b}$ was found to be comparable to that of Ere. Like Ere, the compounds Ib, IIa, IIb, IIId, Va were not significantly active against vancomycin-resistant enterococci ${ }^{10)}$ (Enterococcus faecalis NCTC 12201, Enterococcus faecium NCTC 12202, E. faecalis NCTC 12203. MIC >64 $\mu \mathrm{g} / \mathrm{ml}$ ). Escherichia coli strains (E. coli ESS, E. coli NCTC 10418) were not sensitive to the Ere derivatives $(\mathrm{MIC}>64 \mu \mathrm{g} / \mathrm{ml})$.

\section{Experimental}

General Methods

Eremomycin was produced at the Pilot Plant of the Institute of New Antibiotics, Russian Academy of Medical Sciences. All other reagents and solvents used were commercial products.

IR spectra were determined on a Pye-Unicam SP 1100 instrument in $\mathrm{KBr}, \mathrm{NMR}$ spectra were recorded on a Varian VXR-400 spectrometer.

FAB mass spectra were obtained using a VG $2 \mathrm{AB}$ mass spectrometer fitted with an Ion Tech FAB gun. Samples were applied to the probe tip in a matrix of glycerol - thioglycerol-oxalic acid. Spectra were recorded in profile mode and several scans $(10 \sim 15)$ were acquired into a single data file. The data was then smoothed, peak centroids determined and mass assigned using a series of data system procedures. Ionspray spectra were recorded on a Sciex API III mass spectrometer. Samples were flow injected into the mass spectrometer using $60 \%$ acetonitrile, $38 \%$ water, $2 \%$ acetic acid at a flow of $30 \mu \mathrm{l} /$ minute.

Optical rotations were measured with a Perkin-Elmer-241 polarimeter. HPLC was performed on a DuPont 8800 liquid chromatograph, column $(4.6 \times 250 \mathrm{~mm})$ Zorbax ODS $5 \mu \mathrm{m}$, detector SP8490 $(\lambda 245 \mathrm{~nm})$. Elution was carried out using linear gradient from $100 \% \mathrm{D}$ to $100 \% \mathrm{~F}$, where D: $5 \% \mathrm{CH}_{3} \mathrm{CN}-95 \% 0.1 \mathrm{M}$ $\mathrm{NH}_{4} \mathrm{H}_{2} \mathrm{PO}_{4}$ and $\mathrm{F}: 45 \% \mathrm{CH}_{3} \mathrm{CN}-55 \% 0.1 \mathrm{M} \mathrm{NH}_{4} \mathrm{H}_{2} \mathrm{PO}_{4}$, in 25 minutes at the rate of $1 \mathrm{ml} / \mathrm{minute}$. CM-cellulose column chromatography was performed on a LKB Ultrograd Gradient Mixer 11300, supplied with Uvicord 2138 and Recorder 2065. Preparative TLC was performed on the plates $20 \times 20 \mathrm{~cm}$ coated with Merck Silica Gel $60 \mathrm{~F}_{254}(1 \mathrm{~mm})$. Pre-coated Merck Silica Gel $60 \mathrm{~F}_{254}$ plates were used for TLC in systems: $\mathrm{PrOH}$ - EtOAc - conc. $\mathrm{NH}_{4} \mathrm{OH}, 2: 2: 1$ (A), 3:2:1 (B), 2:2:5 (C).

$N, N$-Dimethyleremomycin (IIa) and Methyl Ester of $N, N$-Dimethyleremomycin (Va)

$\mathrm{NaHCO}_{3}(8 \mathrm{mg}, 0.1 \mathrm{mmol})$ and $\mathrm{CH}_{3} \mathrm{I}(0.04 \mathrm{ml} 0.6 \mathrm{mmol})$ were added to a stirred solution of eremomycin sulfate $(330 \mathrm{mg}, 0.2 \mathrm{mmol}$ ) in $12 \mathrm{ml}$ of DMSO. The reaction mixture was stirred at room temperature for 6 hours. After addition of $200 \mathrm{ml}$ of acetone the precipitated solid was collected by filtration and purified by CM-cellulose column chromatography (column $2 \times 40 \mathrm{~cm}$ ) on CM-32 (Whatman) during 8 hours using gradient of $0.2 \mathrm{M} \mathrm{AcONH}_{4}\left(\mathrm{pH}\right.$ 6.7) - $0.2 \mathrm{M} \mathrm{AcONH}_{4}$ with adding $\mathrm{NH}_{4} \mathrm{OH}$ to $\mathrm{pH}$ 9.3. The solutions which contained IIa or Va were adjusted to $\mathrm{pH} 2$ and passed through column $(0.5 \times 4 \mathrm{~cm})$ of SDW-3 $\left(\mathrm{H}^{+}\right)$resin elution being performed with $0.25 \mathrm{~N} \mathrm{NH}_{4} \mathrm{OH}$. After concentration of the eluates to $3 \mathrm{ml}$ and neutralization to $\mathrm{pH} 6$ with $6 \mathrm{~N} \mathrm{H}_{2} \mathrm{SO}_{4} 100 \mathrm{ml}$ of acetone was added to give the precipitates of IIa $(148 \mathrm{mg}, 45 \%)$ and Va $(67 \mathrm{mg}, 20 \%)$. IIa: Rf 0.31 (C), HPLC Rt 13.2 minutes. Va: Rf 0.48 (C), HPLC Rt 14.6 minutes.

$N$-Allyleremomycin (Ib) and $N, N$-Diallyleremomycin (IIb)

To a stirred solution of eremomycin sulfate $(330 \mathrm{mg}, 0.2 \mathrm{mmol})$ in $12 \mathrm{ml}$ of DMSO, $\mathrm{NaHCO}_{3}(33 \mathrm{mg}$, $0.4 \mathrm{mmol})$ and $\mathrm{CH}_{2}=\mathrm{CHCH}_{2} \mathrm{I}(0.05 \mathrm{ml}, 0.5 \mathrm{mmol})$ were added at room temperature. After 8 hours $\mathrm{NaHCO}_{3}(33 \mathrm{mg})$ and $\mathrm{CH}_{2}=\mathrm{CHCH}_{2} \mathrm{I}(0.05 \mathrm{ml})$ were added and 4 hours later the procedure was repeated. Two hundred $\mathrm{ml}$ of acetone were added to the reaction mixture. The precipitate was collected by filtration and purified by the method described for IIa and Va to yield $115 \mathrm{mg}(35 \%)$ of Ib and $82 \mathrm{mg}$ (25\%) of IIb. Ib: Rf 0.64 (C), HPLC Rt 13.6 minutes. IIb: Rf 0.47 (C), HPLC Rt 15.2 minutes. 
Benzyl Ester of $N$-Benzyleremomycin (IVc) and Benzyl Ester of $N, N^{\prime}$-Dibenzyleremomycin (VIc)

$\mathrm{NaHCO}_{3}(83 \mathrm{mg}, 1 \mathrm{mmol})$ and $\mathrm{C}_{6} \mathrm{H}_{5} \mathrm{CH}_{2} \mathrm{Cl}(0.11 \mathrm{ml}, 1 \mathrm{mmol})$ were added to a stirred solution of eremomycin sulfate $(330 \mathrm{mg}, 0.2 \mathrm{mmol})$ in $13 \mathrm{ml}$ of DMSO. The reaction mixture was stirred at room temperature for 20 hours and $0.11 \mathrm{ml}$ of $\mathrm{C}_{6} \mathrm{H}_{5} \mathrm{CH}_{2} \mathrm{Cl}$ was added. Then the reaction mixture was stirred for 4 hours at $32^{\circ} \mathrm{C}$ and a product was precipitated with $150 \mathrm{ml} \mathrm{Et}_{2} \mathrm{O}$. It was collected by filtration and redissolved in $90 \mathrm{ml}$ of a mixture of $\mathrm{BuOH}-\mathrm{H}_{2} \mathrm{O}(2: 1)$. The solution was washed with $\mathrm{H}_{2} \mathrm{O}(30 \mathrm{ml} \times 3)$, the organic layer was separated and evaporated. The purification was performd by preparative TLC (system B) to yield $70 \mathrm{mg} \mathrm{(20 \% )}$ of IVc and $44 \mathrm{mg}(12 \%)$ of VIc. IVc: Rf 0.48 (A), 0.26 (B). VIc: Rf 0.57 (A), 0.40 (B).

Propyl Ester of Eremomycin (IIId), Propyl Ester of $N$-Propyleremomycin (IVd) and Propyl Ester of $N, N^{\prime}$-Dipropyleremomycin (VId).

$\mathrm{NaHCO}_{3}(50 \mathrm{mg}, 0.6 \mathrm{mmol})$ and $n-\mathrm{C}_{3} \mathrm{H}_{7} \mathrm{I}(0.12 \mathrm{ml}, 1.2 \mathrm{mmol})$ were added to a stirred solution of eremomycin sulfate $\left(330 \mathrm{mg}, 0.2 \mathrm{mmol}\right.$ ) in $15 \mathrm{ml}$ of DMSO. The reaction mixture was stirred at $23^{\circ} \mathrm{C}$ for 24 hours and a product was precipitated with $150 \mathrm{ml}$ of $\mathrm{Et}_{2} \mathrm{O}$. The purification was performed by the method described for IIa and Va to yield $56 \mathrm{mg} \mathrm{(17 \% )} \mathrm{of} \mathrm{IIId,} 43 \mathrm{mg}(13 \%)$ of IVd and $20 \mathrm{mg}(6 \%)$ of VId. IIId: Rf 0.25 (A), 0.09 (B), HPLC Rt 16.6. VId: Rf 0.57 (A), 0.28 (B).

Heptyl Ester of Eremomycin (IIIe), Heptyl Ester of $N$-Heptyileremomycin (IVe) and Heptyl Ester of $N, N^{\prime}$-Diheptyleremomycin (VIe).

(a) $\mathrm{NaHCO}_{3}(50 \mathrm{mg}, 0.6 \mathrm{mmol})$ and $n-\mathrm{C}_{7} \mathrm{H}_{15} \mathrm{I}(0.1 \mathrm{ml}, 0.6 \mathrm{mmol})$ were added to a stirred solution of eremomycin sulfate $\left(330 \mathrm{mg}, 0.2 \mathrm{mmol}\right.$ ) in $12 \mathrm{ml} \mathrm{DMSO}$. The reaction mixture was stirred at $22^{\circ} \mathrm{C}$ for 20 hours and a product was precipitated with $150 \mathrm{ml} \mathrm{Et}{ }_{2} \mathrm{O}$. The purification was performed by the method described for IVc and VIc to yield $63 \mathrm{mg}(18 \%)$ of IIIe, $60 \mathrm{mg}(16 \%)$ of IVe and $47 \mathrm{mg}(12 \%)$ of VIe. IVe: Rf 0.60 (A), 0.40 (B). VIe: Rf 0.65 (A), 0.46 (B).

(b) $\mathrm{NaHCO}_{3}(33 \mathrm{mg}, 0.4 \mathrm{mmol})$ and $n-\mathrm{C}_{7} \mathrm{H}_{15} \mathrm{I}(0.08 \mathrm{ml}, 0.5 \mathrm{mmol})$ were added to a stirred solution of eremomycin sulfate $(165 \mathrm{mg}, 0.1 \mathrm{mmol})$ in $7 \mathrm{ml}$ DMSO. The reaction mixture was stirred at $40^{\circ} \mathrm{C}$ for 2 hours and a product was precipitated with $150 \mathrm{ml} \mathrm{Et}_{2} \mathrm{O}$ and collected by filtration, redissolved in $90 \mathrm{ml}$ of a mixture $\mathrm{BuOH}-\mathrm{H}_{2} \mathrm{O}(2: 1)$. The resulting solution was washed with $\mathrm{H}_{2} \mathrm{O}(50 \mathrm{ml} \times 3)$, the organic layer was separated and concentrated to a small volume $(\sim 2 \mathrm{ml})$. After addition of $100 \mathrm{ml}$ of $\mathrm{Et}_{2} \mathrm{O}$ the precipitate was collected by filtration to yield $26 \mathrm{mg}(15 \%)$ of IIIe. Rf 0.51 (A), 0.23 (B).

\section{Dodecyl Ester of Eremomycin (IIIf)}

$\mathrm{NaHCO}_{3}(25 \mathrm{mg}, 0.3 \mathrm{mmol})$ and $n-\mathrm{C}_{12} \mathrm{H}_{25} \mathrm{Br}(0.1 \mathrm{ml}, 0.4 \mathrm{mmol})$ were added to a stirred solution of eremomycin sulfate $(165 \mathrm{mg}, 0.1 \mathrm{mmol})$ in $8 \mathrm{ml} \mathrm{DMSO}$. The reaction mixture was stirred at $40^{\circ} \mathrm{C}$ for 4 hours and a product was precipitated with $150 \mathrm{ml} \mathrm{Et}{ }_{2} \mathrm{O}$. The purification was performed by the method described for IIIe (b) to yield $27 \mathrm{mg}(15 \%)$ of IIIf. Rf 0.61 (A), 0.44 (B).

\section{Octadecyl Ester of Eremomycin (IIIg)}

$\mathrm{NaHCO}_{3}(25 \mathrm{mg}, 0.3 \mathrm{mmol})$ and $n-\mathrm{C}_{18} \mathrm{H}_{37} \mathrm{Br}(50 \mathrm{mg}, 0.15 \mathrm{mmol})$ were added to a stirred solution of eremomycin sulfate $(165 \mathrm{mg}, 0.1 \mathrm{mmol})$ in $8 \mathrm{ml}$ DMSO. The reaction mixture was stirred at $40^{\circ} \mathrm{C}$ for 8 hours. The purification was performed by the method described for IIIe (b) to yield $25 \mathrm{mg}(13 \%)$ of IIIg. Rf 0.61 (A), 0.54 (B).

\section{Antibacterial Activities}

Antibacterial activity in vitro against Bacillus subtilis ATCC 6633 was determined by the method of serial dilutions in tubes on broth; $1,000 \mathrm{ml}$ of Hottinger hydrolysate with $28 \mathrm{mg} \%$ of amine $\mathrm{N}, 30 \mathrm{~g}$ of agar-agar, $5 \mathrm{~g}$ of peptone and $2.5 \mathrm{~g}$ of $\mathrm{CaCO}_{3}$. Sterilization was performed at $\mathrm{pH} 7.2 \sim 7.4$. Activity of the compounds against 25 methicillin-resistant clinical isolates of Staphylococcus aureus was determined by the method of agar serial dilutions. Agar plates containing $15 \mathrm{ml}$ of agar containing two-fold dilutions of the test agents were inoculated to yield a final density of approximately $10^{7} \mathrm{cfu}$ per spot. The plates were incubated at $35^{\circ} \mathrm{C}$ for 24 hours in ambient air.

Minimal inhibitory concentrations (MIC's) of Ib, IIa, IIb, IIId and Va against an expanded spectrum Gram-positive bacteria (Table 3) were determined by the microtiter dilution method. $12 \times 8$ microtiter 
trays had $50 \mu$ l broth per well. Todd-Hewitt broth was used for Corynebacterium xerosis NCTC 9755 and all enterococci and streptococci except Streptococcus faecalis I for which nutrient broth (Oxoid No 2) was used. Nutrient broth was used for all other cultures. Antibiotic solutions were in doubling dilutions. Inocula were $1 \mu \mathrm{l}$ of a one tenth dilution of overnight broth cultures. Incubation was at $37^{\circ} \mathrm{C}$ overnight.

\section{Acknowledgments}

We gratefully acknowledge I. Hood for fruitful discussion, M. GWYNN for antibacterial data (both from SmithKline Beecham Pharmaceuticals, Brockham Park, United Kingdom) and Dr. D. K. BRYANT (SmithKline Beecham Pharmaceuticals, Old Powder Mills, Tonbridge, Kent, United Kingdom) for ionspray mass spectrometry data.

\section{References}

1) Gauze, G. F.; M. G. Brazhnikova, N. N. Lomakina, T. F. Berdnikova, G. B. Fedorova, N. L. Tokareva, V. N. Borisova \& G. Y. BATTA: Eremomycin-new glycopeptide antibiotic: Chemical properties and structure. J. Antibiotics 42: 1790 1799, 1989

2) Parenti, F. \& B. Covalleri: Novel glycopeptide antibiotics of the dalbaheptide group. Drugs of the Future 15: $57 \sim 72,1990$

3) Nagarajan, R.; D. M. Berry, A. H. Hunt, J. L. Occolowitz \& A. A. Schabel: Conversion of antibiotic A82846B to orienticin and structural relationships of related antibiotics. J. Org. Chem. 54: 983 986, 1989

4) Good, V. M.; M. N. GWynN \& D. J. C. Knowles: MM45289, a potent glycopeptide antibiotic which interacts weakly with diacetyl-L-lysyl-D-alanyl-D-alanine. J. Antibiotics 43: 550 555, 1990

5) BARNA, J. C. J. \& D. H. Williams: The structure and mode of action of glycopeptide antibiotics of the vancomycin group. Annu. Rev. Microbiol. 38: 339 357, 1984

6) Olsufyeva, E. N.; T. F. Berdnikova, N. Y. Dokshina, N. N. Lomakina, G. I. Orlova, I. V. Malkova \& I. N. Prozorova: Eremomycin modification at amino groups. Antibiotiki i Khimiotherapia (Russ) 34: 352 358, 1989

7) Nagarajan, R. \& A. A. Schabel (Eli Lilly and Company): Improvements in or relating to glycopeptide derivatives. Eur. Pat. Appl. 435 503, July 3, 1991 [Chem. Abstr. 116: 6973e, 1992]

8) Pavlov, A. Y.; E. N. Olsufyeva, T. F. Berdnikova, B. V. Rosynov, L. G. Aleksandrova. I. V. Malkova \& M. N. Preobrazhenskaya: Synthesis and antibacterial activity of the antibiotic eremomycin esters. Bioorg. Khimia (Russ.) 17: 849 854, 1991

9) Berdnikova, T. F.; N. L. Tokareva, E. A. Abramova, N. Y. Dokshina, N. P. Potapova \& N. N. Lomakina: A novel polycyclic glycopeptide antibiotic eremomycin. Structure of the aglycone. Antibiotiki i Khimiotherapia (Russ.) 33: 566 570, 1988

10) Uttley, A. H. C.; C. H. Collins, T. Naidoo \& P. C. George: Vancomycin-resistant enterococci. Lancet 1988: $57 \sim 58,1988$ 